\title{
JELAJAH ARKEOLOGI DAN MEMBACA PESAN-PESAN SEJARAH DARI KELAMPAUAN: SUATU PENELITIAN PENDAHULUAN
}

\author{
(Exploring Archeology And Reading Historical Messages Of The Past: \\ A Preliminary Study)
}

\author{
I Made Sutaba \\ Balai Arkeologi Bali \\ Jalan Raya Sesetan 80 Denpasar Bali \\ Pos-el: imdsutaba@gmail.com
}

\begin{tabular}{|c|c|}
\hline INFO ARTIKEL & $A B S T R A C T$ \\
\hline $\begin{array}{l}\text { Histori Artikel } \\
\text { Diterima : } 20 \text { Oktober } 2020 \\
\text { Direvisi : } 9 \text { Maret } 2021 \\
\text { Disetujui : } 7 \text { Juni } 2021\end{array}$ & $\begin{array}{l}\text { Archaeological research in Indonesia until the present days, has } \\
\text { successfully discovered a diverse historical and archaeological } \\
\text { heritage, which are classified as cultural heritage. This cultural } \\
\text { heritage is an advice and source of historical information of the past }\end{array}$ \\
\hline $\begin{array}{l}\text { Keywords: } \\
\text { archaeology, cultural } \\
\text { heritage, historical } \\
\text { consiousness and } \\
\text { nationalism } \\
\text { Kata kunci: } \\
\text { arkeologi, warisan } \\
\text { budaya, kesadaran } \\
\text { sejarah, rasa kebangsaan, } \\
\text { nasionalisme }\end{array}$ & $\begin{array}{l}\text { life of the pluralistic Indonesiain ancestor. This cultural heritage } \\
\text { beared problems, namely the aspect of typology, sociology and } \\
\text { ideology in its contextual relationship that are unlikely to study it now. } \\
\text { This research concentrates on the subjects in its relationship to the } \\
\text { historical of the past and its relevance to the future of the nation } \\
\text { building that not yet studied before. This research is a preliminary } \\
\text { study concerning the historical messages of the past. The purpose of } \\
\text { this research is to find out the answer of the problems. This research is } \\
\text { done through library study for collecting data and the analysis was } \\
\text { carried out using typological approach. The result of this study } \\
\text { indicater a significance messages are the historical counsciousness, } \\
\text { sense of nationalism, and its fundamental relevance for building the } \\
\text { future of Indonesian nation. So far it is impossible to get the complete } \\
\text { historical messages and sense of nationalism due to it characters such } \\
\text { as incomplete, fragile, finite and so on. }\end{array}$ \\
\hline
\end{tabular}

\begin{abstract}
ABSTRAK
Penelitian arkeologi di Indonesia sampai sekarang sudah berhasil menemukan aneka ragam peninggalan sejarah dan purbakala yang merupakan warisan budaya bangsa. Warisan budaya ini adalah bukti dan sumber informasi sejarah mengenai kehidupan nenek moyang bangsa Indonesia yang merupakan masyarakat masa silam yang pluralistic. Kekayaan budaya ini mengandung permasalahan yang mencakup aspek-aspek teknologi, social dan iedologi yang saling berkaitan secara konstekstual, yang tidak mungkin diteliti sekarang. Penelitian ini dipusatkan pada subjek yang berkaitan dengan pesanpesan sejarah dari kelampauan dan relevansinya bagi pembangunan masa depan bangsa, yang belum dikaji sampai sekarang. Seiring dengan permasalahan ini, maka penelitian ini bertujuan untuk mencari jawabannya. Pelaksanaan penelitian didahului dengan pengumpulan data melalui kajian pustaka. Data dikaji lebih dalam dengan melalukan analisis tipologi. Hasil penelitian menunjukkan pesan-pesan yang signifikan berkenaan dengan kesadaran sejarah, rasa kebangsaan dan relevansinya yang bersifat fundamental bagi pembangunan masa depan bangsa Indonesia. Namun demikian, tentu tidak mungkin untuk mendapatkan pesan sejarah dan rasa kebangsaan yang lengkap, karena sifatnya yang tidak lengkap, rapuh, serba terbatas dan lainnya.
\end{abstract}




\section{PENDAHULUAN}

Indonesia adalah bangsa yang lahir dari sejarahnya yang panjang. Sebagai bangsa yang sangat majemuk (multietnik dan multibudaya), hidup berdampingan dalam satu ikatan persatuan dan kesatuan bangsa. Hidup saling menghormati, saling menghargai kesederajatan dalam keberbedaan dan menjunjung tinggi kesetaraan dan kesederajatan (Soebadio, 1986; 18 - 25; Soekmono, 1964: 1 - 16). Kenyataan ini adalah fakta sejarah yang tidak terbantahkan, terbukti dari hasil-hasil penelitian yang dilakukan oleh para ahli sejarah, arkeologi, dan kebudayaan, berupa bukti-bukti bendawi, non bendawi dan sumber informasi sejarah, yang disebut peninggalan sejarah dan purbakala arkeologi, yang sekarang disebut juga sebagai cagar budaya yang diakui juga sebagai kekayaan budaya bangsa yang tidak ternilai (Sutaba, 2015a.: 4 - 7; 2015b.: 213 - 222; Kementerian Pendidikan dan Kebudayaan, 2012).

Cagar budaya adalah bagian yang penting dari warisan budaya bangsa, mengandung nilai-nilai sosio-kultural yang signifikan bagi pengembangan ilmu pengetahuan, sejarah, arkeologi, pendidikan, agama, kebudayaan, geologi, ekologi, paleontologi dan lainnya. Selain itu, cagar budaya juga mempunyai arti penting bagi pembangunan bangsa antara lain, pembangunan bidang pendidikan nasional dan pembangunan industri pariwisata budaya. Cagar budaya ini ternyata mengandung nilai-nilai yang dapat diberdayakan menjadi aset budaya, yaitu nilai-nilai estetik, simbolik, asosiatif, ekonomis dan lain-lainnya (Kementerian Pendidikan dan Kebudayaan, 2012; Ardika, 2015: 30 - 33).

Sebagai salah satu bagian dari warisan budaya bangsa, cagar budaya Indonesia yang jumlah, ragam dan kualitasnya makin bertambah, telah menarik perhatian para peneliti, seperti ahli-ahli arkeologi, sejarah dan kebudayaan. Hal ini terjadi karena cagar budaya ini mempunyai sifat yang sangat spesifik, yaitu rapuh (fragile), tidak lengkap (incomplete), sangat terbatas dalam jumlah (finite), tidak terperbaharui (nonrenewable), tidak dapat dipindahkan (immovable) dan tidak tergantikan (irreplaceable), tetapi selalu kontekstual, baik dalam relasinya dengan space (ruang atau lokasi) dan time atau periode dan bentuk yang diwakilinya (Fagan, 1987: 18 19: 34 - 36; 39: Deetz, 1967: 45; Sutaba, 2015b.: 213 - 222; Sutaba et al., 2006: 9 35). Faktor lainnya, ialah karena sifatnya yang multifasial dan multifungsi, merupakan representasi atau wujud dari keanekaragaman gagasan atau pikiranpikiran dari para penciptanya dahulu kala. 
Oleh karena sifatnya ini, maka koleksi atau temuan cagar budaya tidak mungkin hanya dikaji secara monodisipilin melalui (satu sisi) disipilin arkeologi saja. Harus diteliti melalui cakrawala budaya multi-perspektif terpadu untuk mendapat gambaran yang lebih luas mengenai kehidupan masyarakat masa lalu, seperti pesan-pesan atau informasi sejarah yang mungkin melekat pada setiap potongan-potongan atau bagian-bagian artefak arkeologi. Di samping itu, cagar budaya adalah sumber informasi sejarah yang kredibel mengenai kehidupan masa silam, yang dapat diinterpretasikan dari berbagai aspeknya, seperti aspek teknologi, fungsi dan maknanya (Sedyawati, 2006: 12 - 14; White, 1959: 3 - 32). Kecuali itu, cagar budaya dapat juga dianggap sebagai lambang atau simbol keberhasilan nenek moyang kita dalam hidupnya dahulu kala, yang sudah berhasil menghadapi berbagai kesulitan yang tidak mudah diatasi (Magetsari, 2016: 70 - 73). Oleh karena sifatnya yang pluralistis, maka cagar budaya sebagai rekam jejak perilaku kehidupan masyarakat masa lalu, tentu mengandung berbagai pesan atau informasi sejarah dari kelampauan (historical information of the past) yang menarik perhatian, yang perlu dikaji melalui pendekatan multiperspektif.

$$
\text { Pengalaman di lapangan }
$$

memberikan petunjuk, bahwa sampai sekarang jelajah arkeologi atau archaeological study atau kajian arkeologi selalu menghasilkan temuan penting berupa tinggalan arkeologi yang harus diperhitungkan. Perlu dipahami bersama bahwa setiap temuan baru, sekali pun berukuran sangat kecil, tidak secara sertamerta akan dapat memudahkan penyelesaian permasalahan kearkeologian. Kemungkinan besar akan menambah permasalahan, sebab setiap temuan tinggalan budaya pada umumnya sudah membawa permasalahannya masingmasing. Permasalahan yang timbul di lapangan seringkali $=$ bervariasi antara lain permasalahan teknologi, fungsi, dan latar belakang atau maknanya yang memuat karakter atau kearifan lokal (local genius). Sementara ahli arkeologi berpendapat, bahwa permasalahan ini muncul dari sumbernya, yaitu dari hasil-hasil penelitian, pelestarian, pemanfaatan dan pengembangan cagar budaya, yang menyangkut aspek-aspek fisik, lingkungan alam dan lingkungan sosial di sekitarnya. Dari sudut pandang lain dapat juga dikatakan, bahwa permasalahan yang seringkali muncul, ada yang bersifat teknisarkeologis seperti pelestarian dan nonteknis arkeologis, yang pada umumnya bersifat kontekstual (Sutaba, 2019b.: 111130). Cagar budaya adalah bagian yang tidak terpisahkan dari warisan budaya antara lain, ada yang berupa benda budaya 
atau artefak arkeologi, bangunan, struktur bangunan, situs arkeologi dan kawasan cagar budaya (Kementrian Pendidikan dan Kebudayaan, 2012).

Seperti telah disebutkan di atas, kekayaan budaya ini ternyata mengandung permasalahan yang tidak mudah, karena sangat luas dan kompleks. Permasalahan yang sangat luas, tentu tidak mungkin untuk menelitinya dewasa ini, sehingga memutuskan untuk memilih hanya satu, yaitu mengenai pesan-pesan sejarah dari kelampauan yang dianggap penting dan memprediksi relevansinya bagi pembangunan bangsa ke depan. Sementara itu, data dan fakta mengenai permasalahan ini, masih sangat terbatas. Selain itu, sejauh yang diketahui, sampai sekarang tidak ada penelitian khusus mengenai permasalahan ini, yang mungkin dapat diberdayakan sebagai kapital budaya bagi pembangunan bangsa. Tidak adanya penelitian khusus mengenai permasalahan ini, menimbulkan kesulitan bagi kami ketika mencari bahanbahan rujukan atau referensi dan komparasi yang diperlukan dalam penelitian ini. Walaupun harus menghadapi berbagai kesulitan, tetapi kami telah memutuskan pilihan di atas sebagai penelitian rintisan pendahuluan, yang tentu saja masih perlu dikaji lagi pada kesempatan lainnya. Sejalan dengan pilihan ini, maka penelitian ini bertujuan untuk meneliti dan mencari jawaban terhadap permasalahan di atas, sehingga dapat memberikan pengertian dan pemahaman kepada masyarakat luas mengenai pesan-pesan sejarah dari kelampauan dan relevansinya bagi pembangunan dewasa ini.

\section{METODE PENELITIAN}

Seperti telah dikemukakan di atas, penelitian ini adalah studi pendahuluan (preliminary study) mengenai pesan-pesan sejarah dari kelampauan (the historical messages of the past) dan relevansinya dengan masa kini. Permasalahan ini mungkin selama ini kurang menarik minat para peneliti terdahulu, karena bermacammacam faktor yang tidak dapat diperkirakan tanpa pertimbanganpertimbangan atau alasan-alasan yang jelas. Oleh karena itu, penelitian ini tentu akan menghadapi berbagai kesulitan atau kendala yang tidak mudah. Walaupun demikian, dapat dikemukakan di sini, bahwa penelitian ini bersifat kualitatif, tetapi data kuantitatif akan dipertimbangkan juga sejauh berkaitan erat dengan tujuan penelitian ini. Metode dalam penelitian ini menggunakan pendekatan multidisipliner atau multiperspektif, karena cagar budaya sebagai sumber kajian penting bersifat multifasial dan multifungsi. Oleh karena sifatnya yang pluralistik, cagar budaya menyimpan berbagai aspek atau berbagai informasi mengenai kehidupan dari masa silam, yang kerap kali dipandang juga sebagai misteri 
atau rahasia masa silam yang semakin menarik untuk dikaji. Penelitian ini dilakukan dengan metode kajian pustaka (library research), (Sutaba, 2014: 31 -34; 2019a.: 27 - 42). Kajian pustaka dilakukan terhadap sumber-sumber pustaka, seperti buku-buku, jurnal dan publikasi lainnya, untuk mendapat data sekunder dan pendapat atau teori-teori para peneliti terdahulu yang bertalian dengan penelitian ini.

\section{Analisis Data}

Analisis data merupakan tahap kedua dari pelaksanaan penelitian, yang diawali dengan seleksi data, reduksi data dan pengolahan data sesuai dengan kepentingan penelitian. Aanalisis data selanjutnya adalah pendekatan multiperspektif terhadap warisan budaya, antara lain analisis teknologi.

Walaupun sudah melakukan penelitian dengan menerapkan seperangkat metode penelitian seperti tersebut di atas, tentu tidak metutup kemungkinan adanya kekurangan atau kelemahan-kelemahan yang tidak mudah. Mungkin hal ini terjadi karena berada di luar dugaan kami sebelumnya, karena warisan budaya itu selalu dalam kondisi tidak lengkap dan serba terbatas (Deetz, 1967: 7 - 8; Fagan, 1987: 36; Sutaba et al., 2006: 9 - 35). Berdasarkan pengalaman selama ini, hal semacam ini seringkali terjadi, sehingga diangggap sebagai hal yang wajar.
Kekurangan atau kelemahan ini, hendaknya dapat dianggap sebagai pembuka kesempatan yang penting untuk menerima sumbangan pikiran yang bersifat konstruktif dari berbagai kalangan. Di samping itu kekurangan ini sekaligus juga memberikan peluang untuk melakukan kajian ulang atau elaborasi secara akademik yang mungkin dianggap penting.

\section{HASIL DAN PEMBAHASAN}

\section{Hasil Kajian Literatur}

Sampai sekarang, sebagian akademisi percaya, bahwa arkeologi adalah satu-satunya ilmu yang mempunyai kemampuan yang sangat mengagumkan, karena dapat menembus dunia masa lalu yang penuh dengan misteri dan rahasia kehidupan masyarakat yang sudah musnah. Di sini para ahli arkeologi tidak hanya bekerja untuk kepentingan dirinya sendiri yang bersifat akademis, ideologis dan praktis. Ia juga tidak hanya meneliti artefak-artefak arkeologi saja, melainkan harus juga berusaha untuk menemukan nilai-nilai sosial-budaya yang berserakan. Di antaranya ada yang masih bercampur aduk dan kemudian merangkainya menjadi satu narasi historik-eksplanatif yang mempunyai signifikasi mengenai kehidupan penciptanya. Dalam hal ini para ahli arkeologi berpendapat bahwa artefak arkeologi adalah lambang atau simbol budaya nenek moyang yang mengandung berbagai pengetahuan dari kelampauan atau 
dari sejarah masa silam yang tidak ternilai. Secara arkeologis disebut jati diri bangsa atau kepribadian bangsa yang mempunyai ketahanan budaya bangsa (White, 1959: 3 32). Di samping itu, artefak arkeologi yang disebut juga sebagai warisan budaya, adalah bukti-bukti dan sumber informasi sejarah masa silam yang sangat potensial dan kredibel, walaupun selalu dalam keadaan tidak lengkap (Pusat Penelitian dan Pengembangan Arkeologi Nasional, 2010: i - ii; Soebadio, 1986: 18 - 25; Sedyawati, 2006: 12 - 14; Sutaba et al., 2006: 9 - 35; Fagan, 1987: 36).

Selama ini, masih ada sementara warga masyarakat kita yang menanyakan mengenai pentingnya penelitian arkeologi dalam konteksnya dengan kehidupan abad milenial dewasa ini, ketika pembangunan di Tanah Air tengah mengalami peningkatan yang makin maju, bersamaan juga dengan perkembangan ilmu pengetahuan dan teknologi dunia yang sangat cepat. Pertanyaan semacam ini adalah fenomena sosial, dapat terjadi di mana saja, mungkin disebabkan oleh kurangnya pengetahuan atau pengertian sebagian masyarakat mengenai sejarah atau masa silam yang mengandung informasi mengenai kehidupan nenek moyang dahulu kala. Dalam situasi semacam ini, ahli-ahli purbakala bersama kerabat kerjanya akan hadir untuk berbagi pengetahuan melalui pendekatan edukatif yang bersifat familiar, mengenai pentingnya cagar budaya sebagai bukti sejarah bangsa (Sutaba, 2019a.: 27 42). Berdasarkan hasil-hasil penelitian selama ini dapat diketahui, bahwa penelitian arkeologi, bertujuan untuk mempelajari sejarah kebudayaan, menyusun rekonstruksi kehidupan masa lalu dan meneliti perubahan cara-cara pemenuhan keperluan hidup masyarakat sehari-hari (Fagan, 1987: 19 - 21).

Untuk mencapai tujuan tersebut di atas yang dicanangkan oleh Fagan (1987: 35) ahli-ahli arkeologi melakukan penelitian dengan menerapkan kaidahkaidah kearkeologian, seperti metode penelitian, untuk menggarap dua komponen cagar budaya yang dominan dalam suatu penelitian arkeologi. Pertama ialah situs arkeologi (archaeological site) yang mungkin menyimpan sisa-sisa permukiman (settlement), kuburan kuno dan sisa-sisa aktivitas penghuninya dan lain-lainnya. Artefak arkeologi yang ditemukan di situs ini selalu dalam posisi kontekstual, yaitu mempunyai relasi atau konteks dengan space (lokasi atau tempat) dan time (kronologi atau periode) yang tidak mungkin dipisahkan secara parsial (Fagan, 1987: 35 - 42). Kedua yang tidak kalah pentingnya, ialah artefak arkeologi yang ditemukan dalam penelitian mempunyai berbagai bentuk, fungsi dan makna, yang dapat merefleksikan tanda-tanda atau ciriciri (features) yang merupakan hasil 
perbuatan manusia penciptanya. Secara arkeologis dapat dikatakan bahwa tinggalan arkeologi yang bersifat pluralistik ini adalah hasil dari gagasan-gagasan atau ideide manusia penciptanya (product of human ideas) yang sangat beragam. Para ahli arkeologi dan antropologi budaya berpendapat bahwa hubungan kontekstual antara cagar budaya dengan lokasi, waktu dan bentuknya dengan tinggalan lainnya bersifat sistemik-kontekstual, merupakan masalah penting dalam kajian arkeologi (Deetz, 1967: 53 - 80; Fagan, 1987: 39 79). Sekiranya hubungan ketiga aspek tersebut tidak terdeteksi lagi, karena berbagai faktor yang tidak diketahui dengan jelas, maka tinggalan arkeologi tersebut sudah kehilangan nilai-nilai arkeologisnya sebagai bukti-bukti dan sumber informasi sejarah. Demikianlah tinggalan arkeologi tersebut tidak dapat memberikan kontribusi atau manfaat bagi penelitian selanjutnya.

Penelitian arkeologi pada dasarnya bersifat multidimensional, karena tinggalan arkeologi, seperti cagar budaya, Kawasan cagar budaya dan lainnya yang menjadi sasaran penelitian bersifat jamak, dapat memberikan manfaat: i) teoritis, yaitu melengkapi rekonstruksi kehidupan masyarakat masa lalu; ii) ideologis, yaitu memberikan pengertian dan pemahaman mengenai nilai-nilai sosial-budaya dalam setiap upaya pengukuhkan jatidiri di tengah-tengah pergaulan dunia internasional; dan iii) praktis, yaitu untuk kepentingan pembangunan bangsa, antara lain pembangunan pendidikan dan kebudayaan nasional yang berbasis kepribadian bangsa, dan pembangunan industri pariwisata budaya berbasis kebudayaan dan lingkungan hidup (Kementerian Pendidikan dan Kebudayaan, 2012; Soekmono, 1964: 1 - 16; Tjandrasasmita, 1980: 95 -102; Soebadio, 1992: 1- 9; Soediman, 1983 - 1984: 18 - 24; Hardjasumantri, 1983 -1984: 139 - 142; Sutaba, 2000: 27 - 33).

Dari sisi lain, penelitian arkeologi dapat dibedakan sebagai: i) penelitian murni (pure research), yaitu untuk kepentingan akademis, membangun teoriteori yang dapat diuji dalam suatu penelitian di lapangan atau di laboratorium; dan ii) penelitian terapan (applied research), yaitu untuk kepentingan yang dapat diterapkan atau diimplementasikan di lapangan. Kedua macam penelitian ini tidak dapat dipisahkan, karena keduanya saling bersinergi secara kontekstual, saling memerlukan dan juga saling melengkapi bagi pengembangan penelitian di lapangan. Di samping itu, warisan budaya ternyata mengandung nilai-nilai penting bagi pembangunan bangsa dewasa ini dan ke depan. Nilai-bilai tersebut bermanfaat bagi pembangunan pendidikan nasional dan industri pariwisata budaya dan juga dalam keterkaitannya dengan pengembangan ilmu 
pengetahuan, seperti arkeologi, sejarah, kebudayaan, lingkungan, kehutanan, kedokteran ragawi, arsitektur, geografi, tehnik sipil dan sebagainya. Masih ada nilai-nilai lainnya yang melekat pada cagar budaya sebagai bukti dan sumber sejarah masa lalu, yaitu nilai-nilai estetik, simbolik, ekonomis, informatif dan asosiatif, yang merupakan kapital budaya bagi pembangunan bangsa (Kementerian Pendidikan dan Kebudayaan, 2012; Sutaba, 1998: 5 - 10; Sutaba et al., 2006: 9 - 35; Ardika, 2015: 2; 30 - 33; 104 - 105).

Berdasarkan hasil-hasil penelitian terdahulu dapat diketahui, bahwa berdampingan dengan ahli-ahli arkeologi, hadir juga ahli-ahli antropologi budaya untuk melakukan kajian bersama, karena cagar budaya mempunyai karakteristik yang multifasial dan multifungsi, seperti dikemukakan di atas yang tidak mungkin dapat dikaji hanya dari satu sisi saja atau secara monodisiplin (Sedyawati, 2006: 12 14). Leslie A. White (1959: 3 - 32; 1975) berpendapat, bahwa warisan budaya adalah satu totalitas kehidupan masyarakat yang mengandung aspek-aspek teknologi, sosial dan ideologi atau kepercayaan, yang tidak hanya saling melengkapi, tetapi juga saling tergantung dan menentukan secara sistemis-kontekstual. Lebih lanjut dikatakannya (White 1959) bahwa kemajemukan karakteristik cagar budaya itu, tidak memungkinkan dilaksanakan kajian yang bersifat monodimensional dan parsial. Oleh karena itu diperlukan pendekatan model lain yang lebih komprehensif-holistik, berdasarkan data dan temuan yang tersedia, untuk menjangkau cakupan penelitian yang sangat luas. Sementara itu, L. R. Binford (1978) mengemukakan pendapatnya yang hampir sama dengan pendapat Leslie A. White di atas, tetapi disampaikan dengan rumusannya sendiri. Binford (1978) berpendapat bahwa cagar budaya itu mempunyai unsur-unsur penting yang sangat mengikat secara sistemis, yaitu teknofak (teknologi), sosiofak (sosial) dan ideofak (ideologi). Ketiga unsur ini telah membangun landasan dasar yang kuat bagi pembangunan kehidupan masyarakat, baik dalam konteks lingkungan alam maupun lingkungan sosial di sekitarnya. Dalam perkembangan masyarakat selanjutnya, aspek-aspek atau unsur-unsur kehidupan seperti tersebut di atas adalah tehnologi, sosial dan kepercayaan, merupakan elemen-elemen yang bersifat fundamental dan sangat dominan, tidak hanya sekedar memengaruhi, tetapi sangat menentukan keberhasilan masyarakat membangun dirinya sendiri (White, 1957; 1975).

Keberagaman warisan budaya yang ditemukan di Indonesia telah lama menarik perhatian para ahli arkeologi, sejarah dan kebudayaan, karena kekayaan budaya ini merefleksikan kearifan lokal (local genius) 
yang memuat karakter asli kebudayaan Indonesia seperti telah dikemukakan oleh peneliti terdahulu (Covarrubias, 1972: 26; 167 - 168; Ramseyer, 1977; Cf. Soebadio, 1986: 18 - 25). Sementara itu ada juga kalangan lainnya yang berpendapat, bahwa sebagai bukti dan sumber informasi sejarah, warisan budaya adalah akar budaya-bangsa (national cultural root) yang telah berkembang menjadi konstruksi dasar bangunan budaya bagi perkembangan dan kemajuan Indonesia sepanjang masa (Soebadio, 1980: 7 - 10; 1986: 18- 25; 1991: 1 - 8; 1992: 1- 9; Sutaba, 2015b.: 213 - 222). Ada lagi pendapat lainnya yang menganggap, bahwa cagar budaya itu adalah identitas budaya-bangsa (national cultural identity) atau kepribadian budaya bangsa, yang menjadi penanda atau pengenal yang membedakan dengan bangsa-bangsa lainnya. Dalam perkembangan kebudayaan Indonesia dalam skala regional mempunyai hubungan sejarah dan kebudayaan dengan bangsabangsa Asia Tenggara, Asia Selatan dan Asia Timur. Akan tetapi, nenek moyang bangsa Indonesia mempunyai kemampuan beradaptasi dan mengolah semua pengaruh budaya dari luar, sehingga menghasilkan kebudayaan yang khas Indonesia yang mempunyai ketahanan budaya yang signifikan (Soebandio, 1986: 18-25) Hubungan atau persentuhan budaya semacam ini dapat terjadi, karena secara geografis Indonesia terletak pada titik silang perlintasan perjalanan yang sangat strategis, baik dalam konteks regional maupun internasional (Perry, 1918: 3; Soejono, 2008: 281-294; Sutaba, 1997: 244-251; 1999).

Dalam kontak-kontak sosial budaya seperti disebutkan di atas dapat diduga, bahwa nenek moyang bangsa telah berperan dengan sangat cerdas, yang dijiwai oleh kepribadian budaya, kearifan lokal dan ketahanan budaya yang sudah lama menjadi panduan hidupnya. Selain itu, tentu tidak dapat dibantah, bahwa di masa lalu telah terjadi perkembangan budaya lokal (local cultural development) yang sangat menentukan hadirnya karakter budaya Indonesia yang sangat khas. Hal ini berarti, bahwa masyarakat lokal (local society) di Indonesia sudah melakukan peran yang sangat dinamis, kreatif, fleksibel dan selektif yang disertai dengan tanggungjawabnya sebagai pemilik warisan budaya, yang mempunyai jatidiri yang tangguh (Sutaba, 1999; 2014). Perkembangan kebudayaan, terutama cagar budaya seperti dipaparkan di atas telah menyimpan nilai-nilai sosial budaya penting, ternyata tidak hanya merefleksikan kemajuan teknologi masa lalu (ancient technology), tetapi memberikan juga informasi yang berharga mengenai nilainilai (values) kehidupan masyarakat dan mengenai pemanfaatannya dalam 
kehidupan sehari-hari (Fagan, 1987: 28). Demikianlah cagar budaya sebagai akar budaya bangsa, mengandung aspek-aspek teknologi, sosial dan ideologi atau kepercayaan menjadi fondasi dan sekaligus menjadi panduan dalam kehidupan bangsa, seperti telah dipaparkan oleh Leslie A. White dan L. R. Binford. Demikianlah, seperti telah dsampaikan oleh I Made Sutaba (2019a.: 27 - 42), cagar budaya itu dapat berfungsi sebagai penutur kehidupan masa silam (the teller of the past life), yang meliputi aspek-aspek kehidupan masyarakat yang bersifat multidimensional, walaupun tidak dapat dihindari adanya kekurangan atau keterbatasannya, karena berbagai faktor yang tidak mudah diketahui (Fagan, 1987: 36). Warisan budaya, sebagai kekayaan budaya bangsa yang tidak ternilai, adalah kapital atau sumber daya budaya yang dapat diberdayakan bagi pembangunan untuk sebesar-besarnya kemakmuran bangsa, dengan tidak mengabaikan karakter dan daya tahan budaya bangsa. Persebaran peradaban global dewasa ini, yang ditandai oleh kemajuan teknologi, terutama teknologi transportasi dan teknologi informatika, telah mengakibatkan hilang atau kaburnya batas-batas geografis-kultural antarbangsa atau antarnegara, sehingga terjadi borderless country atau dunia tanpa batas, dan mungkin juga kebudayaan menjadi kabur (Magetsari, 2016: 11 -12; 16 - 17; Tilaar, 2007: 27).

Cagar budaya adalah warisan budaya yang merupakan akar budaya, dapat diberdayakan sebagai sumber inspirasi, referensi dan alternatif-alternatif pilihan bagi pembangunan bangsa. Dewasa ini dan ke depan, supaya kita tidak tercerabut dari akar budaya yang merupakan identitas atau kepribadian budaya bangsa yang dibangun oleh nenek moyang kita (Sutaba, 1999; Soebadio, 1986: 18 - 25; Magetsari, 2016: 1 - 9; Sedyawati, 2006: 12 - 14). Noerhadi Magetsari (2016:367-370) berpendapat bahwa akar budaya sesungguhnya adalah suatu kesadaran sejarah yang sudah lama tumbuh dan berkembang sesuai dengan kemajuan masyarakat. Kesadaran sejarah bangsa sendiri sebenarnya dapat dipandang sebagai pertanda, bahwa sejak dahulu kala nenek moyang bangsa sudah memiliki pengertian dan pemahaman mengenai pentingnya sejarah, sehingga dapat menumbuhkan kebanggaan sejarah bangsa sendiri hingga batas-batas yang tidak berlebihan, yang kemudian mendorong lahirnya rasa kebangsaan atau nasionalisme.

Cagar budaya yang multifasial dan multifungsi dapat juga dipandang sebagai konstruksi dasar bangunan budaya, yang dapat dimanfaatkan sebagai panduan pembangunan selanjutnya (Soebadio, 1992: 1-9; Hardja-Sumantri, 1983: 139-142; 
Soediman, 1983-1984: 18-24). Selain itu, cagar budaya ini adalah cultural record yang merupakan dokumen budaya dan sekaligus pusaka budaya bangsa yang tidak hanya cukup sekedar diwacanakan saja, tetapi lebih dari itu harus dijaga bersamasama, diapresiasi, dijunjung tinggi dan dilestarikan. Pusaka budaya bangsa, baik fisik (budaya tangible) maupun nilai-nilai yang dikandungnya (budaya intangible) penting bagi pembangunan bangsa berbasis sejarah dan kebudayaan sepanjang zaman.

Dalam pembangunan bangsa dewasa ini, cagar budaya sebagai sumberdaya budaya adalah modal unggulan yang tidak ternilai, tetapi kerap kali dianggap sebagai sumber konflik kepentingan (conflict of interest) di antara berbagai pihak yang mengadu untung dalam pemanfaatan dan pengembangan cagar budaya (Sulistyanto, 2010: 1-16, Hadiyanta, 2017: 37-139). Praduga semacam ini, tentu saja tidak selamanya benar, karena konflik kepentingan yang seringkali muncul, mungkin tidak secara keseluruhan berdampak destruktif, tetapi mungkin ada juga yang bersifat konstruktif. Konflik kepentingan tersebut perlu diteliti secara komprehensif-holistik, supaya dapat diperoleh solusi yang saling menguntungkan (win-win solution) bagi semua pihak yang terlibat, termasuk penduduk lokal (Skeats, 2004; Ardika,
2015: 1; 57 - 58; Sulistyanto, 2010: 1 -16; Tanudirdjo, 1998: 14 - 18).

Sehubungan dengan konflik kepentingan seperti disebutkan di atas, barangkali dapat dicegah, terlebih dahulu dengan merancang Cultural Resource Management $(C R M)$, suatu upaya pengelolaan sumberdaya budaya, yang mencakup pemanfaatan dan pengembangan cagar budaya, antara lain untuk kepentingan industri pariwisata budaya. Dalam hal ini, kepentingan arkeologi bukanlah satu-satunya bagian sentral, karena di luarnya terdapat berbagai kalangan yang berkepentingan untuk turut serta mengambil kesempatan berinvestasi. Oleh karena itu, berbagai pihak seperti ahli arkeologi, pemangku kepentingan kepariwisataan dan komponenkomponennya sebaiknya duduk Bersama sejak awal pembahasan perencanaan secara transparan-profesional, pelaksanaan dan evaluasi hasilnya. Masyarakat lokal (local society) agar diberi peluang yang sebesarbesarnya untuk turut serta dalam setiap tahap kegiatan, sehingga segala kepentingannya yang bersifat sosialbudaya tidak terabaikan begitu saja.

Pada bagian lain, para ahli yang relevan dengan pengelolaan warisan budaya seperti ahli arkeologi, ahli sejarah, ahli kebudayaan, ahli industri pariwisata budaya, kalangan ahli ekonomi, pebisnis kepariwisataan dan unsur-unsur lainnya, 
seyogyanya menjadi mitra kerja yang patut dihargai. Selain itu, kalangan media sosial atau media massa yang sangat potensial dan beragam, perlu kiranya diturutsertakan dalam rancangan Cultural Resource Management (CRM) ini bersama-sama dan dengan pihak Social Corporate Responsibility (SCR) yang dapat menambah kekuatan tim pengelolaan warisan budaya yang akan bekerja secara professional, sehingga konflik yang mungkin terjadi pada suatu saat, dapat diselesaikan bersama-sama dengan baik atau dicegah sedini mungkin (Magetsari, 2016: 394 - 407; Sutaba, 2019b.: 111 - 130; Hadiyanta, 2017: 37 - 139; Fagan, 1987: 91; Sulistyanto, 2010: 1 16; Tanudirdjo, 1998: 1418 ; Skeats, 2004). Selain itu, perlu juga diajak bekerjasama, ialah lembaga-lembaga sosial (kemasyarakatan), seperti $N G O$ (Non-Government Organization) yang telah berkembang dalam masyarakat kita.

Hasil-hasil penelitian selama ini menunjukkan, bahwa ahli-ahli arkeologi berpendapat, bahwa agar budaya sebagai warisan budaya adalah kekayaan budaya yang sangat potensial dapat dimanfaatkan sebagai sarana dalam pembangunan rasa kebangsaan atau nasionalisme (Magetsari, 2016: 13 - 15; Soebadio, 1980: 7 - 10; 1986: 18 - 25; Soejono, 2003: 1 - 19; 2005; Sutaba, 1994: 227 - 240; 2000: 27 - 33; Clark, 1960: 251 -264; Fagan, 1987: 201 202; Ardika, 2015: 32 - 33). Berbicara

mengenai pembangunan nasionalisme atau rasa kebangsaan, tentu semua pihak dapat sepakat, bahwa pekerjaan ini tentu tidak mudah, karena kemajemukan bangsa kita yang jumlahnya ratusan juta tersebar di seluruh negeri, masing-masing mempunyai kebudayaan dan tradisinya sendiri-sendiri yang sejak dahulu kala telah berakar dalam hidupnya. Walaupun demikian, tentu akan terbuka berbagai jalan yang dapat diupayakan oleh pemerintah bersama segenap unsur masyarakat untuk membangun rasa kebangsaan (nasionalisme) berbasis sejarah dan kebudayaan bangsa melalui jalur pendidikan nasional, yang merupakan sarana penting yang dapat menjangkau seluruh wilayah. Pendidikan nasional menjadi makin penting, karena sejak dini sudah dapat memberikan pengertian, pemahaman dan penghayatan kepada masyarakat luas, khususnya kepada generasi muda, mengenai pentingnya cagar budaya yang mengandung nilai-nilai sosialbudaya, sehingga dapat menumbuhkan kesadaran sejarah, kebanggaan dan kecintaan kepada warisan budaya nenek moyang kita. Jalur pendidikan nasional ini, seyogyanya direncanakan secara professional, berkelanjutan dan secara bersama-sama. Pendidikan nasional harus dijaga supaya tidak sampai tertular oleh paham-paham etnosentrisme, radikalisme, ideologi politik atau paham lainnya yang 
tidak sesuai dengan kepribadian Indonesia, dan penyalahgunaan doktrin agama dan unsur-unsur lainnya.

Berkenaan dengan pembangunan bagi kepentingan seluruh bangsa yang sangat pluralistik, maka pembangunan pendidikan nasional seyogyanya dirancang menjadi program prioritas nasional skala utama dengan semangat Bhinneka Tunggal Ika (diversity in unity) dan Indonesia-sentris dalam satu rumah bersama, yaitu Negara Kesatuan Republik Indonesia (NKRI). yang maju dan modern, tetapi tetap berkepribadian dan berkarakter yang khas Indonesia. Semua pihak hendaknya mempunyai satu persepsi yang sama, mengenai pembangunan pendidikan nasional yang berbasis sejarah dan kebudayaan bangsa atau yang berdasarkan konstruksi dasar kepribadian bangsa, adalah pembangunan manusia dan kebudayaan (PMK) Indonesia yang sangat menentukan masa depan 'nasib negeri kita' bagi lebih dari 260 juta warga, di tengahtengah derasnya pengaruh budaya global (Cf. Kementerian Pendidikan dan Kebudayaan, 2018). Dalam hal ini harus dipahami dan dimaknai bersama, bahwa pertama, cagar budaya adalah sumberdaya budaya bangsa yang sangat potensial dan kredibel; dan kedua, pembangunan sumberdaya manusia berbasis budaya dan sejarah bangsa, tentu bukan hanya sebagai pilihan saja, tetapi lebih merupakan satu keharusan dan tuntutan sejarah bangsa bagi pembangunan bangsa, supaya di kemudian hari kita tidak kehilangan identitas dan karakter yang khas Indonesia. Pendidikan nasional berbasis sejarah dan kebudayaan adalah kunci wasiat penentu keberhasilan pembangunan bangsa berbasis sejarah dan kebudayaan bangsa, supaya di kemudian hari generasi penerus bangsa kita tidak kehilangan berkepribadian Indonesia yang sudah dibangun dengan susah payah oleh nenek moyang bangsa (Soekmono, 1964: 116).

\section{Kesadaran sejarah}

Berdasarkan hasil-hasil penelitian dan merujuk kepada hasil-hasil pemikiran teoritik para ahli arkeologi, sejarah dan kebudayaan terdahulu, maka kami berpendapat, bahwa pesan-pesan sejarah dari kelampauan yang tidak ternilai (invaluable historical messages of the past) antara lain, kesadaran sejarah (historical consciousness) yang diwariskan oleh nenek moyang bangsa. Secara arkeologis-historis telah terbukti, bahwa pesan sejarah ini, telah lahir dan tumbuh dari peninggalan sejarah dan purbakala (historical and archaeological heritage) bersifat jamak, yang disebut juga sebagai cagar budaya (Kementerian Pendidikan dan Kebudayaan, 2012). Sebagai bukti dan sumber informasi sejarah (evidence and source of historical information), cagar budaya (archaeological heritage) adalah bagian penting dari 
warisan budaya bangsa (national cultural heritage) yang mengandung nilai-nilai sejarah (Sutaba, 2015a.: 4 -7; 2015b.: 213 222; Fagan, 1987: 34 - 36). Dari sisi lain, penulis berpendapat, bahwa warisan budaya adalah rekam jejak kehidupan masyarakat masa silam yang multidimensional sangat potensial dan kredibel, tetapi mempunyai berbagai kelemahan. Walaupun demikian, cagar budaya, selain diyakini sebagai identitas atau kepribadian budaya bangsa, dapat juga dipandang sebagai pusaka budaya bangsa yang sarat dengan pesan-pesan dan kandungan nilai-nilai sosial-budaya masa silam, termasuk ketahanan budaya. Sementara itu, cagar budaya juga dianggap sebagai akar budaya bangsa dan sebagai satu--satunya media komunikator antara masa kini dengan masa silam (Soebadio, 1980: 7 - 10; Magetsari, 2016: 367 - 370).

Noerhadi Magetsari (2016: 370) berpendapat, bahwa cagar budaya sebagai akar budaya bangsa sesungguhnya adalah kesadaran sejarah dari nenek oyang bangsa.

Berdasarkan pertimbanganpertimbangan arkeologis-historis penulis berpendapat, bahwa bangsa Indonesia sudah mempunyai kesadaran sejarah yang sebenarnya berakar dalam sejarah masa lampau. Hal ini dibuktikan dari sejumlah temuan peninggalan sejarah dan purbakala yang oleh para ahli dianggap sebagai sumber informasi sejarah yang sangat berharga. Dalam perkembangan kehidupan nenek moyang yang makin maju, maka kesadaran sejarah bangsa telah mendorong lahirnya pengertian, pemahaman dan penghayatan mengenai pentingnya nilainilai sejarah atau nilai-nilai sosial-budaya yang berkembang dalam masyarakat masa silam (Sedyawati, 2006: 330 - 331; Magetsari, 2016: 1 - 9; 367 - 370; Soebadio, 1986: 18 - 25; Sutaba, 1999). Salah satu contoh penting yang dapat dikemukakan di sini, ialah Candi Borobudur, yang tidak hanya menjadi kebanggaan bangsa Indonesia, tetapi sudah diakui oleh dunia internasional sebagai Warisan Budaya Dunia. Demikianlah warisan budaya ini menjadi labang keberhasilan dan kejayaan bangs akita dalam bidang arsitektur, seni pahat, pranata sosial dan system kepercayaan yang dijiwai oleh karakter kebudayaan asli Indonesia (Soekmono, 1973). Seiring dengan kehidupan yang makin maju, maka kesadaran sejarah yang sudah berakar dalam kehidupan masyarakat memberikan peluang bagi tumbuh dan berkembangnya kebanggaan sejarah dan kebudayaan masa lalu (historical and cultural pride of the past). Dalam perkembangan masyarakat yang makin maju, diperlukan sikap yang cerdas supaya kebanggaan sejarah dan budaya bangsa tidak melanggar alur sejarah yang berbasis kepribadian budaya dan karakter yang khas Indonesia. 
Belajar dari pesan sejarah ini, maka penulis berpendapat, bahwa nenek moyang bangsa Indonesia sudah memberikan pesan sejarah yang tampaknya sederhana, tetapi sangat bermakna (meaningful) dalam ungkapan tutur yaitu atita (masa silam; Bahasa Sanskerta), nagata (masa kini; Bahasa Sanskerta) dan wartamana (masa yang akan datang; Bahasa Sanskerta) (K. Atmodjo, 1986: 46 - 53; Soekmono, 1973). Pesan ini menunjukkan adanya keberlanjutan hidup masyarakat, yang secara historis-kontekstual tidak terputuskan, tetapi berkesinambungan dan saling memengaruhi. Demikianlah, pembelajaran sejarah (dan kebudayaan) nenek moyang bukanlah pekerjaan yang sia-sia, melainkan sangat penting sebagai upaya untuk menguatkan jati diri dan ketahanan budaya bangsa untuk menghadapi pembangunan masa depan yang tidak mudah. Dalam pembelajaran sejarah dapat ditemukan esensi sejarah antara lain, esensi segala keberhasilan, kegagalan dan kendala-kendala atau kesulitan-kesulitan yang berdatangan, sehingga tidak terjadi pengulanganpengulangan yang tidak perlu dan juga tidak berbuat kesalahan-kesalahan yang sama seperti pada masa lalu. Hal ini berarti, bahwa ke depan pembelajaran sejarah (dan warisan budaya) bangsa secara professional-holistik, tidak hanya sekedar keperluan bersama, tetapi harus dimaknai sebagai tuntutan sejarah dan kebudayaan bangsa, yang tidak boleh diabaikan begitu saja. Bagi bangsa Indonesia, berguru kepada sejarah bangsa, menjadi wajib hukumnya, karena sejarah adalah guru yang sangat bijak, yang disebut juga sebagai guru sepanjang zaman dalam kehidupan masyarakat. Belajar sejarah bangsa dapat juga dianggap sebagai upaya investasi untuk menyiapkan diri dalam menghadapi masa sekarang dan membangun masa depan yang sangat kompleks dan rumit.

Seperti dipaparkan di atas, masyarakat Indonesia sejak dahulu kala sudah mempunya kesadaran sejarah yang tampak dalam kesehariannya sebagai warisan masa silam. Kesadaran sejarah ini adalah salah satu contoh yang dapat disaksikan Ketika segenap bangsa merayakan Ulang Tahun Proklamasi Kemerdekaan setiap tanggal 17 Agustus. Secara gotong royong segenap masyarakat melakukan berbagai persiapan tanpa mempersoalkan keanekaragaman. Seluruh bangsa dengan kesadaran sejarah, beramairamai larut dalam suasana perayaan Hari Bersejarah yang sangat penting. Di seluruh Tanah Air, kenyataan ini dapat dipandang sebagai wujud nyata kesadaran sejarah bangsa Indonesia yang merefleksikan pentingnya memahami dan menjunjung tinggi sejarah kebudayaan bangsa. Semangat kebangsaan ini dengan segala kegiatan yang berkaitan erat dengan 
kesadaran sejarah dapat dijadikan panutan Bersama yang mengikat dalam kehidupan bermasyarakat kita yang sangat majemuk.

\section{Rasa Kebangsaan}

Pesan lain dari sejarah masa lalu atau dari kelampauan yang sebenarnya tidak kalah pentingnya dari kesadaran sejarah, adalah rasa kebangsaan (nasionalisme, nationality) yang tumbuh dari kebanggaan kepada sejarah dan budaya yang telah dibangun oleh nenek moyang kita yang bermula dari akar budaya bangsa. Dalam kehidupan masyarakat yang makin berkembang dengan pesat, kesadaran sejarah mendorong bangkitnya kebanggaan sejarah dan budaya (historical and cultural pride) masa lalu. Akhirnya kebanggan tersebut menumbuhkan rasa kebangsaan atau nasionalisme, yang merupakan aset yang sangat potensial bagi pembangunan bangsa ke depan. Kesadaran sejarah dan budaya yang sudah membangun persatuan dan kesatuan bangsa dengan pengertian, pemahaman dan penghayatan mengenai pentingnya nilai-nilai sejarah masa silam, kemudian melahirkan rasa kebangsaan sebagai pengikat bangsa makin mantap (Magetsari, 2016: 13 -15; 367 -370; Soejono, 2003: 1 - 9; 2005; Fagan, 1987: 101 - 102; Clark, 1960: 251 - 264; Sutaba, 1994: 227 -240; 2000: 27 - 33; Ardika, 2015: 32 - 33).

Dalam perspektif kebangsaan, sebagai bangsa yang multietnik dan

multibudaya, terutama pada era milenial ini, kesadaran sejarah dan rasa kebangsaan, adalah pesan-pesan sejarah dari kelampauan yang luar biasa, merupakan kekuatan atau aset sosial-budaya bangsa Indonesia dalam pembangunan bangsa ke depan. Selain itu, pesan-pesan sejarah penting dari kelampauan, dan nilai-nilai sosial-budaya dapat berfungsi sebagai arahan atau panduan, dan juga sebagai referensi dan alternatif-alternatif pilihan bagi pembangunan bangsa kita. Pesan sejarah ini juga mengandung ketahanan budaya bangsa, yang merupakan kekuatan nasional yang signifikan dalam menghadapi pengaruh budaya global dan pengaruh pekembangan budaya bangsa sendiri. Ketahanan budaya bangsa meupakan aspek penting supaya kita tidak kehilangan jati diri yang signifikan atau yang khas Indonesia dan juga tidak hanyut dalam perpecahan internal yang tidak menguntungkan.

Setiap bangsa tentu mempunyai kesadaran sejarahnya sendiri, seperti bangsa Indonesia. Menurut sejarahnya kesadaran sejarah ini berasal dari akar budaya bangsa yang menjadi pendorong lahirnya kebanggaan sejarah dan kebudayaan, yang kemudian menumbuhkan rasa kebangsaan tanpa mempersoalkan keberagaman etnik dan budaya. Dari kesadaran sejarah ini telah tumbuh ketahanan budaya bangsa yang 
berfungsi selektif, protektif, tapi tetap kreatif terhadap segala pengaruh budaya asing dan juga domestik. Telah terbukti bahwa ketahanan budaya bangsa Indonesia tidak kalah pentingnya dengan ketahanan dalam bidang-bidang kehidupan lain, seperti bidang ekonomi, sehingga dalam pembangunan ini bangs akita tidak kehilangan identitas dan karakter kebudayaan asli Indonesia.

Sebagai bangsa yang sangat majemuk, seyogyanya fakta sejarah ini dimaknai bersama sebagai produk sejarah yang sangat panjang, yang sudah menyatukan kita dalam keberbedaan yang kompleks. Kesadaran sejarah dan rasa kebangsaan yang merupakan pesan-pesan sejarah masa silam telah merajut kehidupan bangsa kita dalam kesatuan dan persatuan dengan berbasis sejarah dan warisan budaya, dengan semangat atau sepirit sejarah masa silam. Dalam situasi dan kondisi kehidupan bangsa yang berkembang makin maju, dalam keberbedaan ini telah tumbuh bersama dengan rasa saling menghormati, dengan rasa kesederajatan dan menjunjung atau menghargai kesetaraan dan dengan menyampingkan segala perbedaan yang tidak esensial. Kehidupan bangsa semacam ini, pesan-pesan sejarah dapat dianggap sebagai investasi sosial-budaya yang dapat diberdayakan sebagai aset nasional unggulan untuk memperkuat identitas dan ketahanan budaya. Memperkuat identitas dan ketahanan budaya menjadi makin penting, karena kita tidak mungkin untuk membebaskan diri dari segala pengaruh perkembangan peradaban dunia internasional yang sangat pesat, sebagai akibat dari kemajuan dan penggunaan teknologi yang makin canggih. Kemajuan teknologi telah meniadakan kendalakendala waktu, kesulitan batas-batas geografis dan variabel kultural atau kesulitan lainnya. Oleh karena itu, pesanpesan sejarah dari kelampauan, seyogyanya dijadikan suatu program pembelajaran sejarah dan budaya bangsa secara berkelanjutan, berencana dan profesional melalui berbagai jalur pemerintah yang tersedia dengan melibatkan semua lapisan masyarakat dan media sosial yang sudah tersedia, atau unsur-unsur kemasyarakatan lainnya.

Sebagai bangsa yang sangat majemuk, yang sdang melaksanakan pembangunan ke depan, maka rasa kebangsaan dengan kesadaran sejarah harus dibangun Bersama-sama dengan semangat gotong royong tanpa menghitung keanekaragaman bangsa. Rasa kebangsaan sebagai satu bangsa yang mempunyai ketahanan budaya, adalah pengikat dan pemersatu bangsa yang berasal dari satu akar budaya. Persatuan, kesatuan bangsa dan rasa kebangsaan adalah kekuatan bangsa yang perlu dikembangkan di seluruh nusantara agar dapat menjadi panutan 
bangsa sepanjang masa, supaya pembangunan kita berhasil dengan semangat kepribadian bangsa sendiri.

\section{Relevansi pembangunan}

Pesan sejarah dari kelampauan berikutnya yang diwariskan oleh nenek moyang bangsa Indonesia yang mengandung nilai-nilai sosial-budaya penting adalah hubungan relevan yang sangat fundamental bagi pembangunan masa depan bangsa seutuhnya termasuk pembangunan fisik. Nilai-nilai sosialbudaya tersebut sangat potensial dapat dijadikan panduan sejarah dan budaya, sehingga pembangunan kita tidak kehilangan arah sejarah dan budaya yang telah diwariskan oleh nenek moyang kita. Selain itu, nilai-nilai ini adalah kekuatan budaya bangsa, yang dapat juga digunakan sebagai pedoman, dan alternatif pilihan dalam pembangunan berkelanjutan. Kesinambungan sejarah bangsa yang tidak pernah putus, diwarnai oleh perubahanperubahan untuk mencapai kemajuan, tetapi semuanya berlangsung dalam batasbatas sejarah dan budaya bangsa dan rasa kebangsaan yang kuat. Jika pembangunan bangsa ke depan, terutama pembentukkan karakter manusia Indonesia seutuhnya, khususnya generasi milenial, dilakukan tidak berbasis sejarah dan budaya sendiri yang sarat dengan ketahanan budaya, berarti, pembangunan kita tidak lagi memanfaatkan modal sosial-budaya bangsa, dapat juga dianggap, bahwa kita sudah meninggalkan kepribadian dan jatidiri bangsa sendiri. Dari sisi lain dapat juga dikatakan, bahwa pembangunan kita sudah keluar dari alur sejarah masa lalu dan sudah mengingkari warisan budaya bangsa. Hasil pembangunan yang sudah meninggalkan akar sejarah bangsa sendiri, maka dalam skala nasional, akan mengundang resiko yang sangat rawan dan tidak mudah diprediksi. Di samping itu kita tidak mungkin juga bebas dari pengaruh dan goncangan peradaban dunia internasional yang dipacu oleh keberhasilan ilmu pengtetahuan dan teknologi, seperti teknologi informatika, komunikasi, transportasi dan lain-lainnya. Oleh karena itu, pembangunan bangsa Indonesia ialah tidak boleh kehilangan kepribadian dan jati diri bangsa, dengan cara bersatu padu dalam NKRI. Pembangunan bangsa Indonesia harus berbasis sejarah dan budaya bangsa, kepribadian bangsa dan tetap dalam rajutan Bhinneka Tunggal Ika. Dalam hal ini, perioritas penting yang harus dibangun secara berkelanjutan dan secara professional-komprehensif oleh pemerintah dan segenap bangsa, melaksanakan pembangunan manusia dan kebudayaan. Pembangunan manusia dan kebudayaan Indonesia ke depan harus sama sekali tidak boleh terpapar oleh hal-hal yang bersifat destruktif seperti paham radikalisme, paham etnosentrisme, penyalahgunaan atau 
penyimpangan doktrin agama, serta segala aspek yang tidak sesuai dengan semangat kepribadian dan jati diri warisan nenek moyang bangsa Indonesia.

$$
\text { Pembangungan Indonesia }
$$
mencakup bidang kehidupan yang sangat luas dan kompleks untuk meningkatkan taraf hidup bnangsa di seluruh Tanah Air. Untuk mencapai tujuan ini, Pemerintah tentu sudah melaksanakan berbagai kajian yang bersifat profesional-holistik. Tentu tidak terlewatkan kajian mengenai relevansi yang sangat fundamental mengenai nilai-nilai kehidupan masa silam, sepertipembangunan kemaritiman. Sebagai negara maritime yang besar, belajar dari kemaritiman masa silam, pemerintah sekarang membangun kemaritiman sebagai kesinambungan pembangunan yang konstekstual dan sangat relevan. Pemerintah membuka peluang yang sebesar-besarnya bagi keikutsertaan masyarakat kitai dalam berbagai kegiatan yang dianggap perlu atau sesuai dengan rencana pemerintah sehingga selanjutnya dapat menjadi panutan bersama.

\section{PENUTUP}

Kesimpulan ini masih bersifat sementara atau tentatif, yaitu berupa asumsi-asumsi permulaan, tetapi sangat penting, yang perlu dikaji dan dielaborasi lagi secara akademik-professional pada kesempatan lainnya. Pertama, kesadaran sejarah, adalah pesan sejarah dari kelampauan, yang dianggap sebagai the extraordinary messages of the past, yang lahir dan tumbuh dari akar budaya bangsa (the national cultural root), kemudian berkembang menjadi kepribadian atau identitas nasional, yang menjadi penanda atau ciri-ciri kultural yang spesifik Indonesia. Seiring dengan bergulirnya waktu, kesadaran sejarah dalam kehidupan masyarakat telah menumbuhkan pengertian, pemahaman dan penghayatan mengenai pentingnya nilai-nilai sejarah atau nilai-sosial-budaya dari kelampauan yang diwariskan oleh nenek moyang kita. Dalam kemajuan masyarakat yang makin maju dan meluas, kesadaran sejarah ini berkembang menjadi kebanggaan sejarah dan budaya bangsa, dapat menyatukan seluruh bangsa kita yang sangat majemuk. Menghadapi perkembangan masyarakat yang makin maju dan di sisi makin majunya penyebaran pengaruh peradaban dunia yang bersifat global, maka pemerintah bersama segenap bangsa seyogyanya menjaga supaya perkembangan kesadaran dan kebanggaan sejarah dan budaya bangsa, tidak sampai melampaui koridor sejarah dan budaya bangsa sendiri, supaya bangsa kita tidak kehilangan jati diri yang menjadi landasan pembangunan ke depan.

Kedua, rasa kebangsaan adalah pesan sejarah yang sangat penting, yang juga merupakan the extraordinary historical messages of the past, hampir 
tidak berbeda dengan pesan pertama tersebut di atas. Mencermati perkembangan semacam ini kami berpendapat, bahwa rasa kebangsaan (nasionalisme) adalah suatu perkembangan yang sangat maju dan fenomenal dari kebanggaan sejarah dan budaya bangsa, yang harus dimaknai sebagai modal sosial-budaya yang mempunyai ketahanan budaya bangsa. Kesadaran sejarah dan nasionalisme seharusnya dimaknai sebagai suatu investasi besar bagi keberlanjutan pembangunan bangsa ke depan, berbasis sejarah dan budaya bangsa, sehingga kepribadian bangsa menjadi makin kokoh. Ke depan, pembangunan manusia dan kebudayaan nenek moyang seharusnya menjadi bagian sentral yang sangat urgen, karena merupakan dua kekuatan bangsa yang sangat menentukan, baik yang bersifat kualitatif maupun kuantitatif. Perlu juga dicatat di sini, bahwa men power (penduduk) dan cultural force (warisan budaya) kita adalah modal utama bersama dengan berbagai potensi kekayaan lainnya. Satu lagi yang harus di maknai dengan seksama, ialah pembangunan kebudayaan yang majemuk selaku kekuatan pemersatu bangsa, yang dapat berfungsi sebagai kekuatan penyeimbang atau penyelaras pembangunan nasional yang sangat luas dan kompleks

Ketiga, kesadaran sejarah dan rasa kebangsaan, adalah pesan-pesan sejarah dari kelampauan yang mengandung nilainilai sosial-budaya, ternyata mempunyai relevansi yang sangat fundamental bagi pembangunan masa depan bangsa, karena nilai-nilai sejarah ini dapat berfungsi menjadi arahan dan panduan sejarah dan budaya bangsa, sehingga pembangunan kita tidak pernah kehilangan cultural identity yang sudah berakar dalam kehidupan bangsa kita. Pembangunan bangsa ke depan, seyogyanya lebih diarahkan kepada pembentukkan atau pembangunan manusia Indonesia, terutama generasi milenial yang mempunyai karakter dan ketahanan budaya bangsa, yang berbasis sejarah dan kebudayaan sendiri. Jika pembangunan tidak lagi memanfaatkan atau tidak lagi mendayagunakan nilai-nilai budaya masa lampau, maka hal ini berarti, bahwa kita sudah meninggalkan kepribadian sendiri. Dalam skala nasional, hal ini juga berpotensi sangat rawan, karena di era postmodern ini, kita sudah berada dalam laju pusaran pengaruh budaya global yang sangat cepat. Bagi bangsa Indonesia yang sangat mejemuk, tidak ada lagi pilihan lain, kecuali membangun manusia dan kebudayaan (PMK) bangsa berbasis sejarah dan budaya supaya bangsa Indonesia tetap dalam alur sejarah bangsa, mempunyai jati diri dan ketahanan budaya yang khas Indonesia, di tengah-tengah pergaulan internasional yang makin kompetitif. 


\section{DAFTAR PUSTAKA}

Ardika, I Wayan. 2015. Warisan Budaya, Perspektif Masa Kini (Penyunting Jiwa Atmaja), Udayana University Press.

Binford, L. R. 1978. Working at Archaeology, Academic Press, New York. Chitambar, J. B., 1987. Introduction to Rural Sociology, Willey Estern Limited New Delhi Bangalore Bombay Calcutta Madras.

Clark, Grahmme. 1960, Archaeology and Society, University Paperback Methuen London.

Covarrubias, Miguel. 1972. Island of Bali, Oxford University Press Kuala Lumpur-SingaporeJakarta.

Deetz, James. 1967. Invitation to Archaeology, American Museum Science Books.

Fagan, Brian M. 1987. Archaeology A Brief Introduction, Third Ed. Scott, Foresman and Company, Glenview, Illinois Boston London.

Hadiyanta, Ign Eka. 2007. Dinamika Pelestarian Cagar Budaya, Penerbit Ombak.

Hardjasumantri, Kusnadi. 1983-1984. “Peranan Arkeologi Dalam Pembangun- an”, dalam Majalah Analisis Kebudayaan Th. IV. No. 3, Departemen Pendidikan dan Kebdayaan, Jakarta: 139 - 142.

K. Atmdjo, M. M. Sukarto. 1986. "Pengertian Local Genius dan Relevansinya dalam Mosernisasi” dalam Ayatrohaedi (Penyunting) Kepribadian Budaya Bangsa (Local Genius), Pustaka Jaya: 46 - 53.

Kementerian Pendidikan dan Kebudayaan Republik Indonesia. 2012. Undang-undang Republik Indonesia No. 11 Tahun 2010 Tentang Cagar Budaya.

Kementerian Pendidikan dan Kebudayaan Republik Indonesia. 2018. Undang-undang Republik Indonesia No. 5 Tahun 2017 Tentang Pemajuan Kebudayaan.

Magetsari, Noerhadi. 2016. Perspektif Arkeologi Masa Kini Dalam Konteks Indonesia (Penyunting Irmawati Marwoto, Ali Akbar), Kompas Penerbit Buku.

Perry, W. J. 1918. The Megalithic Culture of Indonesia, Manchester University Press LondonLongsman, Green \& Co.

Ramseyer, Urs. 1977. The Art and Culture of Bali, Oxford University Press New York.

Sedyawati, Edi. 2006. Budaya Indonesia, Kajian Arkeologi, Seni dan Sejarah, Devisi Buku Perguruan Tinggi, PT. Raja Grafindo Persada, Jakarta.

Skeats, Robin. 2004. Debating the Archaeological Heritage, Dutchworth.

Soebadio, Haryati. 1980. "Mencari Akar Kebudayaan Nasional", dalam Majalah Analisis Kebudayaan No.1 Th. 1. Departemen Pendidikan dan Kebudayaan, Jakarta: 7 -10. 
Soebadio, Haryati. 1986. "Kepribadian Budaya Bangsa", dalam Ayatrohaedi (Penyunting) Kepribadian Budaya (Local Genius), Pustaka Jaya, Jakarta: 18 - 25.

Soebadio, Haryati. 1991. Kesinambungan Nilai Budaya Indonesia Dalam Era Pembangunan Nasional II, Denpasar: 1 - 8.

Soebadio, Haryati. 1992. "Arkeologi dan Pembangunan Sosial-budaya", dalam Pertemuan Ilmiah Arkeologi VII, 26 - 30 Juli di Malang: 1 - 9.

Soediman. 1983 - 1984. "Peranan Arkeologi Dalam Pembangunan Nasional', dalam Majalah Analisis Kebudayaan No.1 Th. IV, Departemen Pendidkan dan Kebudayaan, Jakarta; $18-24$

Soejono, R. P. 2003. “Arkeologi Indonesia Dalam Rentangan Nasional dan Interansional”, dalam Guratan Budaya Perspekif Multikulural Katur Ri Kala Purnabakti Prof. Dr. I Gusti Ngurah Bagus (Penyunting I Gede Semadi Astra, Aron Meko Mbete, Ida Bagus Puja Astawan, I Nyoman Darma Putra), Fakultas Sastra dan Budaya UNUD.: 1 - 9.

Soejono, R. R. 2005.” Archaeology, Culture and Nation Building”, dalam International Seminar on Archaeology and Nation Building, Penang, Malaysia (inpress).

Soejono, R. P. 2008. Sistem-sistem Penguburan Pada Akhir Masa Prasejarah di Bali, Disertasi, UI. Dan Pusat Penelitian dan Pengembangan Sumberdaya Kebudayaan dan Pariwisata, Departemen Pariwisata dan Kebudayaan. Soekmono, 1964. "Pemeliharaan dan Penggunaan Bahan-bahan Sejarah”dalam Majalah Ilmu-ilmu Sastra Indonesia No. 1 Th. II: $1-16$.

Soekmono. 1973. Satu Abad Usaha Penyelamatan Candi Borobudur, Yogyakarta, Penerbit Yayasan Kanisius.

Sulistyanto, Bambang. 2010. Resolusi Konflik Dalam Managemen Warisan Budaya Sangiran, Disertasi UI. Depok.

Sutaba, I Made. 1994. "Penelitian Arkeologi Sumbangan Bagi Pembangunan Berwawasan Budaya”, dalam Jejak-jejak Budaya Persembahan Untuk Prof. Dr. R. P. Soejono (Penyunting Sumiati Atmosudiro, Anggraini, Tular Sudarmaji), Diterbitkan oleh Asosiasi Prehistorisi Indonesia Rayon II Yogyakarta: 227 -240.

Sutaba, I Made. 1997. "Indonesia Dalam Globalisasi 2000 Tahun yang Silam”, dalam Persembahan Alumn Jurusan Arkeologi UGM. kepada Prof. Dr. Soekmono (Dewan Redaksi Adrisijanti M. Romli dkk.), Dterbitkan oleh Panitia Lustrum FS. UGM.: 224 - 251.

Sutaba, I Made. 1998. "Preservation of Living Monuments in Bali and Its Problems" dalam SPAFA Journal of the SEAMEO Center for Archaeology and Fine Arts, May-August, Bangkok, Thailand: 5-10. 
Sutaba, I Made. 1999. Keberagaman Dalam Perkembangan Tradisi Megalitik di Indonesia, Disampaikan pada Pengukuhan Jabatan Ahli Peneliti Utama, Departemen Pendidkan dan Kebudayan Republik Indonesia, Pusat Penelitian Arkeologi Nasional, Jakarta 1 Juni.

Sutaba, I Made. 2000. "Manfaat Arkeologi Dalam Pemberdayaan Masyarakat Pada Milinium Ketiga", dalam Forum Arkeologi No. 11/Nop.: 27 - 33.

Sutaba, I Made. 2014. Tahta Batu Prasejarah di Bali, Telaah Tentang Bentuk dan Fungsinya, Penerbit Program Pascasarjana Universitas Hindu Indonesia, Denpasar.

Sutaba, I Made. 2015a. "Pelestarian Cagar Budaya Membangun Ketahanan Budaya Bangsa", dalam Bulletin Sudamala, Dietrbitkan oleh Balai Pelestarian Cagar Budaya Bali: 4 - 7.

Sutaba, I Made. 2015b." Cagar Budaya: Antara Potensi dan Ancaman”, dalam Jurnal Kebudayaan, Vol. 10. No. 3. Desember, Pusat Penelitian dan Kebijakan Pendidikan dan Kebudayaan, Badan Penelitian dan Pengembangan, Kementerian Pendidikan dan Kebudyaan: $213-222$.

Sutaba, I Made. 2019a. “Cagar Budaya, Sang Penutur Masa Silam: Sebuah Penelitian Pendahuluan”, dalam Jurnal Kebudayaan Vol. 14.No. 14. No. 1. Pusat Penelitian dan Kebijakan Pendidikan dan Kebudayaan, Badan Penelitian dan Pengembangan, Kementerian Pendidikan dan Kebudayaan: 27 - 42. Sutaba, I Made, 2019b. "Perawatan Warisan Budaya Membangun Masa Depan Bangsa, Sebuah Penelitian Pendahuluan”, dalam Jurnal Arkeologi Papua Vol. 11. No. 2-Nopember: 111 - 130.

Sutaba, I Made. A. A. Gd. Oka Astawa, I Made Suantra, 2006. "Gianyar Dalam Perspektif Arkeologi”, dalam Gianyar Selintas Narasi dan Harapan Dari Seni Budaya Tantangan dan Peluang Gianyar Membangun: 9 - 35.

Tilaar, H. A. R. 2007. Mengindonesia Etnisitas dan Identitas Bangsa Indonesia Tinjauan Dari Perspektif Ilmu Pendidikan, Penerbit Rineka Cipta.

Tanudirdjo, Daud Aris. 1987. Laporan Penelitian Penerapan Etnoarkeologi di Indonesia, FS. dan Kebudayaan UGM.

Tanudirdjo, Daud Aris. 1998. "Cultural Management Konflik”, dalam Bulletin Artefak, HIMA FSUGM, Yogyakarta: 14 - 18.

Tjandrasasmita, Uka. 1980. "Fungsi Peninggalan Sejarah dan Purbakala Dalam Pembangunan Nasional", dalam Majalah Analiisis Kebudayaan, Kementerian Pendidikan dan Kebudayaan No. 1 Th. 1: 95 - 102.

White, Leslie A. 1959. The Evolution of Culture the Devekopment of Civilization to the Fall of Rome, New York - Toronto - London McGraw - Hill Book Company, Inc. 
White, Leslie A. 1975. The Concept of Culture, A Key to Understanding Tribes and Nation, Columbia University Press New York. 